Article

\title{
The Anatomy of Medium-Scale Farm Growth in Zambia: What Are the Implications for the Future of Smallholder Agriculture?
}

\author{
Nicholas Sitko * and Jordan Chamberlin \\ International Development Agricultural, Food, and Resource Economics, Michigan State University, \\ Rm 207, Justin S Morrill Hall of Agriculture, East Lansing, MI 48824, USA; \\ E-Mail: chamb244@msu.edu
}

* Author to whom correspondence should be addressed; E-Mail: njsitko@gmail.com; Tel.: +260-979-109-790; Fax: +260-211-261-199.

Academic Editors: Annelies Zoomers, Femke van Noorloos, Guus van Westen and Ward Anseeuw Received: 26 May 2015 / Accepted: 10 September 2015 / Published: 18 September 2015

\begin{abstract}
Lost in the debates about the appropriate scale of production to promote agricultural growth in Africa is the rapid expansion of medium-scale farmers. Using Zambia as a case study, this article explores the causes and consequences of this middle-tier transformation on the future of small-scale agriculture. Combining political economic analysis with household survey data, this article examines the relationships between the growth in medium-scale farmers and changing conditions of land access, inequality, and alienation for small-scale farmers. Growth of medium-scale farmers is associated with high land inequality and rapid land alienation in high potential agricultural areas. This growth is shown to be partially driven by wage earner investment in land acquisition and is leading to substantial under-utilization of agricultural land. These processes are both limiting agricultural growth potential and foreclosing future options for an inclusive agricultural development strategy.
\end{abstract}

Keywords: small-scale agriculture; medium-scale farmer; land alienation; land commodification

\section{Introduction}

Land in sub-Saharan Africa (SSA) occupies an increasingly prominent and contested place in debates over food security, the future of the global food system, and "appropriate" economic 
development strategies. After decades of low global food prices, the 2007/08 global food price spike prompted many to question the global food system's capacity to meet future food demand in the context of peak oil, diminishing soil and water resources, and climate change [1,2]. As uncertainty in the global food system mounts, sub-Saharan Africa is seen as the "last frontier of global agriculture"; a massive region, largely left out of the green revolution, with low aggregate population densities, and ample water resources [3]. As this new narrative unfolds, the intensification of agricultural production on African land is increasingly seen an important element in ensuring that global food supplies keep pace with growing demand. As investments in African land accelerate, the conditions under which small-scale farmers control and access land are changing.

Most academic and media attention on the growing interests in African land and land intensification has focused on two divergent investment areas. The first is the rapid increase in global investments in African land for the large-scale production of food and fuel crops [4]. Schoneveld (2014) [5] provides the most recent and well-documented analysis of the scale of these investments in Africa. He identifies a total of 563 acquisitions comprising 22.7 million hectares in Africa since 2005. This is a relatively conservative estimate, because he excludes acquisitions smaller than 2,000 hectares. That said, this conservative estimate is equivalent to 9.6 percent of the total area under cropland in SSA in 2012 (according to FAOSTAT), and roughly 11 percent of the roughly 200 million hectares of the potentially available cropland in SSA [4]. The scale and pace of these acquisitions have raised concerns about their current and future effects on land availability for small-scale agriculture $[2,6]$.

The second strategy involves a substantial reinvigoration in donor and domestic government spending to increase food crop productivity on small-scale farms. In the wake of the 2008 G8 L'Aquila joint statement on food security, OECD countries ramped up spending on agricultural development. As of 2011 OECD countries had allocated $\$ 11.7$ billion to food and nutrition security spending, up 49\% from 2002 in real terms [7]. As a result, food and nutrition security spending makes up about 7\% of overseas development assistance from the OECD, $61 \%$ of which is spent on agricultural development (2008-2010). As of 2009, Sub-Saharan Africa received 41\% of this total spending [7]. At the same time, the NEPAD-led Comprehensive African Agricultural Development Programme (CAADP) has help spur some African governments to increase domestic spending on agriculture, primarily through increases in large-scale input subsidy programs [8].

In many ways, these divergent investment waves in African land and agricultural production reflect broader debates over what the appropriate scale of production is for meeting domestic food and food security policy objectives and enhancing stability in global food markets. On the one hand, many development economists argue that igniting a "new" green revolution in Africa, through targeted investments in seed, fertilizer, and output markets for small-scale farms, is the most effective way of transforming food systems and economies in the region $[9,10]$. On the other hand, there is a growing minority who argue that the combined challenges of rapid urban food demand growth, climate change, and persistent stagnation in African small-scale production systems require new approaches, including the expansion of commercial agricultural production on the continent [11].

Largely unrecognized in these stylized debates over commercial versus small-scale production is the growing population of medium-scale farmers in SSA. These are farmers that own or control more than 5 hectares and generally less than 100 hectares of land. They are differentiated from traditional small-scale farmers by the scale of their land holdings; among small-scale farmers in SSA the vast 
majority ( $70 \%)$ controls less than 2 hectares of land [12]. Yet in most cases these medium-scale farms lack the hallmarks of commercial farming operations in the region, including utilization of production financing, crop irrigation, and mechanization. As shown by Jayne et al. 2014 [13], several countries in SSA have, over the last decade, witnessed a meteoric increase in the number of medium-scale farmers. While this may reflect a process of land consolidation associated with economic transformation [14], there are reasons for concern. Case studies and media reports from the region suggest that an important drivers of the growth in medium-scale farms is land acquisitions by wage earners, often for speculative purposes or for future use in retirement, not agricultural-led consolidation [15-17]. While land consolidation by a relatively elite minority is not a new phenomenon in much of Africa (see [18-20]) the scope and scale of this process is [13]. As medium-scale land acquisitions reshape the African agricultural landscape, they are likely to have important implications on the effectiveness of donor and domestic government spending to achieve broad-based growth outcomes and the repercussions of large-scale land acquisitions on the future of small-scale agriculture.

As global and domestic interest in securing access to African land increases, important questions emerge about the consequences of this largely unnoticed middle-tier land rush in SSA on the future of African agriculture. Using data from Zambia, this article examines the role played by medium-scale land acquisitions in shaping the potential to achieve inclusive, agricultural-led growth. In particular, this article analyzes the spatial and socio-economic implications of medium-scale land acquisitions on land access, land ownership inequality, and land use in Zambia. By exploring these underappreciated dimensions of the African land rush, we hope to provide insights into the role of domestic land policies and land investors in shaping the future of Africa's food system.

The remainder of the article is organized as follows. Section 2 details the data used in this article. This is followed by a detailed description of the political economic context of the growth of mediumscale land holders in Zambia. In Section 4 we analyze various spatial dimensions of the expansion of medium-scale land holdings, with particular attention to its relationships with land access, land alienation, and land inequality conditions in high potential agricultural areas. Section 5 explores the socio-economic characteristics and land use patterns of these medium-scale land holders, relative to small-scale farmers in Zambia. Section 6 offers concluding remarks.

\section{Data and Methods}

In this article, we draw from nationally representative household survey data of small and medium scale farmers in Zambia. In particular, we draw on various Crop Forecast Surveys (CFS), the 2001 Supplemental Survey, and the 2012 Rural Agricultural Livelihoods Survey (RALS). The CFS is carried out annually by the Ministry of Agriculture and the Central Statistical Office. It is the largest survey of agricultural households in Zambia, with average household sample sizes of over 12,000 households. The sample frame for the CFS allows for the generation of district representative data on small and medium scale farms. However, the CFS suffers from several limitations. First, the CFS did not collect data on total land holdings until 2009. As such, information on total land holding, which we use to categorize medium and small-scale farms, is not available at a district level until 2009. Second, the CFS does not collect data on important dimensions of rural livelihoods such as off-farm income and livestock ownership. To fill these gaps we rely on the Supplemental Survey 2001 and the RALS 
2012. However, these surveys are only provincially representative, and therefore cannot be used to assess changes at the district level.

The CFS, Supplemental Survey, and RALS collect data on the "smallholder" farming sector in Zambia. For the purpose of these surveys, a smallholder household is defined as cultivating less than 20 hectares of land. Therefore, the surveys include farmers that own more than 20 hectares of land, but cultivate 20 hectares or less. This leads to a systematic oversampling of farmers that under-utilize their land. While we acknowledge this limitation, its overall effect on the subsequent analysis is limited. When we calculate the number of households excluded from enumeration in the CFS due to land cultivation size, we find that only 0.02 percent of listed households exceeded the 20 hectare cultivation limit for enumeration. We therefore do not anticipate that this land cultivation limit significantly effects the overall conclusions from the data. However, due to this selection criterion these surveys have limitations with regards to our analysis. However, additional concerns with the data exist. First, because only households that have cultivated some portion of their land are included, these surveys exclude individuals who have acquired land that is sitting idle. Second, these surveys may fail to capture data on households that own land but whose primary residence is urban. Finally, these surveys do not capture the timing of land acquisitions, the income source used to finance land acquisitions, or previous employment information.

To fill this gap, we draw on a survey of medium-scale land holders conducted in 2011 by Sitko and Jayne (2014) [15]. This survey was carried out with 183 individuals with land holdings of five or more hectares. The survey was administered in July 2011 in four districts in Zambia: Mumbwa, Choma, Kalomo, and Mpongwe. The four districts were purposively selected based on the concentration and number of emergent farmers in the 2010 CFS. To ensure a reasonable concentration to sample from, at least 3 percent of all farmers in the district had to be classified as emergent farmers. We selected districts along a continuum of concentrations to ensure geographic diversity in the sample. However, it is important to note that emergent farmers are overwhelmingly concentrated in districts that are in close proximity to the "line of rail" and the urban mining areas of the "Copperbelt". Of the 72 District in Zambia, Kalomo District had the highest concentration of emergent farmers in the country (15\%), Mumbwa had the third highest concentration with nine percent, Mpongwe was tied for seventh with five percent, and Choma was tied for ninth with a 3\% concentration level. Farmers meeting were randomly selected from farmer contact lists kept by the Zambian National Farmers Union (ZNFU) and the District Agriculture and Cooperatives Office (DACO). While in all likelihood these lists are not exhaustive, they provided the only viable means for randomizing our sample of emergent farmers in each of the districts. The data presented here are, therefore, not nationally representative, but they do provide indicative findings on the emergent farming sector in districts where emergent farmers are concentrated.

\section{The Context of Medium-Scale Farm Growth: Land Policies, Agricultural Spending, and Economic Change}

Before examining the domestic land rush in Zambia, it is important to first situate it in the context of Zambia's land administration policies, agricultural public spending, and on-going economic transformations. Like much of SSA, Zambia's land is administered through what Mamdani (1996) [21] referred to as a "bifurcated" system of land administration. On the one hand, so-called state land is 
allocated to individuals or corporations on long-term transferable leases administered by the central government. On the other hand, customary lands are allocated on a usufruct rights basis through a system of "traditional authorities," such as chiefs and headmen. Apart from these broad designations, however, there is very limited coordination or clarity regarding land administration in Zambia (see Sitko et al. 2014 [22] for a detailed historical account of Zambia's land policies). Indeed, Zambia does not have an overarching land policy in place, and has not had one for decades.

Complicating the policy vacuum for land is Zambia's 1995 Land Act, which provides the legal framework to convert customary land to leasehold title, but does not spell out its socio-economic goals or objectives. Under the 1995 Land Act, traditional authorities can grant consent to individuals or corporations to convert land under their authority to leasehold title. After a perfunctory approval from the District Council the land is permanently removed from customary control, and becomes both transferable and collateralizable. Under this system, there are virtually no legal protections for customary rights holders on land designated for alienation, no system for tracking the quantities and locations of land removed from customary control, and no obvious mechanism for local resident to alienate their land [22,23]. The interaction of formal statutory bodies and informal institutions, including land allocation system among traditional authorities that are rarely codified, leads to conversion processes that are opaque and subject to significant manipulation by more powerful segments of society [24]. There is evidence suggesting that wealthy Zambian urbanites approach traditional authorities and offer payments in return for the traditional authorities' consent to alienate land to foreign investors [24].This is likely a similar process by which medium-scale domestic land investors acquire and alienate land. As shown by Sitko et al. 2014 [22], land title acquisition by small and medium-scale farmers is a function of, among other things, being considered "non-local" to the area, having higher levels of education, and having access to wage income, particularly from the public sector. Thus, higher levels of financial and social capital appear necessary to navigate the existing system for alienating land in Zambia.

The legal capacity to alienate customary land, coupled with the continued lack of a broader policy regulating land use and administration, coincides with sweeping socio-economic changes in Zambia. Over the last decade Zambia has experienced GDP growth rates of over 6 percent, making it one of the fastest growing economies in the world. This has contributed to the rise of a Zambian middle class, yet has failed to improve incomes for the majority of the population, particularly those in rural areas where headcount poverty rates hover at nearly 80 percent. For the purpose of this discussion two facets of this growth in income inequality deserve attention. First, a large segment of Zambia's wage earning population has seen their disposable income increase substantially, but without a similar increase in investment opportunities. With land policies favorable to low cost land acquisition and alienation, land has become an increasingly attractive investment asset for wage earners with disposable incomes [15]. Second, with wage incomes growing and urban populations expanding, domestic food demand is growing, and is projected to continue to grow substantially [25]. As a consequence of these factors, Zambia has witnessed a transformation in incentives to invest in agricultural land acquisitions and the wherewithal to do so.

Coupled with an ill-defined system of land alienation and administration is an agricultural public spending portfolio that has shifted substantial toward providing input and output market subsidies for maize cultivation. Beginning in 2008 the Government of Zambia began allocating between 50 to $80 \%$ 
of the total agricultural budget to maize subsidy programs [26]. While this expansion of subsidies has helped push Zambia above the 10 percent budget target set by CAADP, these subsidies disproportionately favor larger land holders, with the capacity to cover the cost sharing components of the input subsidy program and to produce surplus maize to sell to the government's Food Reserve Agency at above market prices.

Table 1 presents the distribution of participation in the input subsidy program (proxied for by subsidized fertilizer) and quantities of maize produced by land groups. What is clear is that while medium-scale farmers make up a small share of the rural population, they capture a majority of government spending on agriculture. For example, in Column D shows the average kg of fertilizer a household receives from the government's Farmer Input Support Programme. This Programme is designed to provide $200 \mathrm{~kg}$ of fertilizer to so-call "vulnerable but viable" small-scale farmers. Yet, as shown in Column D, farmers with less than 5 hectares of land receive on average less than the prescribed fertilizer amount, while medium-scale farmers acquire more the prescribed amount. This is a direct result of targeting criteria that favor wealthier, larger-scale producers, and make it virtually impossible for poor, small-scale producers to participate [27].

This targeting of larger, better-off farmers is an explicit attempt to ensure national food security in maize, measured in terms of aggregate surplus maize production. With a history of maize price riots leading to political change, Zambian policy-makers tend to focus myopically on national maize supplies to ensure their political legitimacy [28]. Yet, because poverty and food insecurity is concentrated among small-scale farmers, this spending regime has proven incapable to effectively driving down rural poverty or improving food insecurity outcomes [27].

Table 1. FISP fertilizer received (2010/11 crop season) and expected maize sales, 2011, by farm size category. Source: MACO/CSO Crop Forecast Survey, 2010/11. Reproduced from Jayne et al. 2011 [29].

\begin{tabular}{|c|c|c|c|c|c|c|c|}
\hline $\begin{array}{c}\text { Total Area } \\
\text { Cultivated } \\
\text { (Maize + All } \\
\text { Other Crops) }\end{array}$ & $\begin{array}{l}\text { Number } \\
\text { of Farms }\end{array}$ & $\begin{array}{c}\% \text { of } \\
\text { Farms }\end{array}$ & $\begin{array}{c}\text { \% of Farmers } \\
\text { Receiving } \\
\text { Subsidized } \\
\text { Fertilizer } \\
\end{array}$ & $\begin{array}{c}\text { kg of Subsidized } \\
\text { Fertilizer } \\
\text { Received per } \\
\text { Farm Household } \\
\end{array}$ & $\begin{array}{c}\text { \% of Total } \\
\text { Subsidized } \\
\text { Fertilizer by } \\
\text { Land Size } \\
\end{array}$ & $\begin{array}{c}\text { \% of } \\
\text { Farmers } \\
\text { Expecting to } \\
\text { Sell Maize } \\
\end{array}$ & $\begin{array}{c}\text { Expected } \\
\text { Maize Sales } \\
\text { (kg/farm } \\
\text { household) }\end{array}$ \\
\hline $0-0.99$ ha & 596,334 & $39.6 \%$ & $14.3 \%$ & 24.1 & $12 \%$ & 22.2 & 135 \\
\hline $1-1.99$ ha & 499,026 & $33.1 \%$ & $30.6 \%$ & 69.3 & $30 \%$ & 47.7 & 609 \\
\hline $2-4.99$ ha & 354,116 & $23.5 \%$ & $45.1 \%$ & 139.7 & $43 \%$ & 64.0 & 1,729 \\
\hline $5-9.99$ ha & 49,410 & $3.3 \%$ & $58.5 \%$ & 309.7 & $13 \%$ & 82.1 & 6,613 \\
\hline $10-20 \mathrm{ha}$ & 6,999 & $0.5 \%$ & $52.6 \%$ & 345.6 & $2 \%$ & 86.8 & 15,144 \\
\hline Total & $1,505,885$ & $100 \%$ & $28.6 \%$ & 77.1 & 100 & 42.7 & 950 \\
\hline
\end{tabular}

With supportive agricultural public spending policies and conducive land alienation policies, Zambia has witnessed rapid growth in medium-scale landownership and resultant land concentration. As shown in Table 2, the majority of Zambia's farms is less than five hectares in size and has, since 2001 , seen an annual growth rate commensurate with population growth of 2.5 percent. Conversely, medium-scale farmers with five hectares and more, and particularly those over 10 hectares, have seen growth rates outstripping normal population growth. As a result of this rapid growth, the share of farmland in Zambia controlled by the medium-scale minority has expanded considerably. While 
medium-scale land owners still make up only 18 percent of the farming population, as of 2014 they controlled over 57 percent of the total farmland in the sector. If the commercial farm sector were included the total share of farmland controlled by the 1.1 million household with less than 5 hectares of land would be even lower.

Table 2. Changes in farm structure among small- and medium-scale farmers in Zambia (2009-2012). Source: Ministry of Agriculture Supplemental Survey 2001 and Crop Forecast Surveys 2009 and 2014.

\begin{tabular}{ccccccc}
\hline Landholding & \multicolumn{3}{c}{ Number of Farms } & \multirow{2}{*}{ \% Change } & \% of Total Small and Medium-Scale Land \\
\cline { 2 - 3 } Size & $\mathbf{2 0 0 1}$ & $\mathbf{2 0 0 9}$ & $\mathbf{2 0 1 4}$ & $\mathbf{( 2 0 0 1 - 2 0 1 4 )}$ & $\mathbf{2 0 0 9}$ & $\mathbf{2 0 1 4}$ \\
\hline $0-2 \mathrm{ha}$ & 597,310 & 916,787 & 762,685 & $27 \%$ & $24.1 \%$ & $15.3 \%$ \\
$2-5$ ha & 339,165 & 366,628 & 434,035 & $28 \%$ & $33.8 \%$ & $26.9 \%$ \\
$5-10$ ha & 125,103 & 110,436 & 176,533 & $41 \%$ & $20.3 \%$ & $23.5 \%$ \\
$10-20$ ha & 36,799 & 35,898 & 65,737 & $79 \%$ & $12.3 \%$ & $17.1 \%$ \\
$20-100$ ha & 13,056 & 9,030 & 19,320 & $48 \%$ & $9.5 \%$ & $17.2 \%$ \\
Total & $1,111,433$ & $1,438,779$ & $1,460,324$ & $31 \%$ & $100.0 \%$ & $100.0 \%$ \\
\hline
\end{tabular}

On the face of it, the consolidation of agricultural land in Zambia by medium-scale farmers may be read as a positive transformation; one that is consistent with the stylized narrative of small-scale farmer-led process of land accumulation and consolidation resulting from economic structural transformation [30,31]. Drawing primarily on analysis from the Green Revolution experience in Asia, the literature on economic structural transformation outlines a fairly linear process by which agricultural productivity growth on small-scale farms transforms largely agrarian economies into more industrial ones. The stylized facets of this transformation are: (i) the process starts with agricultural productivity growth among the rural majority of small-scale producers; (ii) small-scale but productive farmers with sufficient land to produce a surplus will lead this process; (iii) the money that they mobilize from their surplus production and spend stimulates demand for goods, services and jobs in the various off-farm sectors of the economy, which induces rural-urban migration, gradual urbanization, and a slow or negative rate of population growth in rural areas. Agriculture becomes a "declining sector" as its share of total GDP falls over time. Over time, consolidation of farmland occurs as rural areas gradually depopulate and more efficient producers rent or buy land from their less efficient neighbors, who leave agriculture and migrate to cities [32]. Yet, given the political economic context of this growth, and the pace at which it is occurring, there are concerns that it may reflect a more worrying and nefarious process. To better understand the implications of the rapid consolidation of agricultural lands by a medium-scale minority of farmers, we explore the spatial relationships between this process and broader conditions of smallholder land access, land inequality, and land alienation.

\section{The Geographic Dimensions of Medium-scale Farm Growth}

Zambia is a large country, covering approximately $750,000 \mathrm{~km}^{2}$, with a low average population density of less than 20 people per $\mathrm{km}^{2}$. Yet, a large segment of this population is clustered around the major infrastructure routes, called the "line of rail", stretching from the south of the country, through the capital city Lusaka, then branching east to the Tanzanian border and west through the industrial 
region of Zambia's "Copperbelt" (Figure 1). The importance of the "line of rail" to Zambian economic life cannot be overstated. For agriculture, proximity to the line of rail is critical for accessing markets, as transactions costs increase marketed as distance from the line of rail increases. Thus, land access and availability for small-scale farmers along the line of rail is of critical importance to processes of agricultural commercialization.

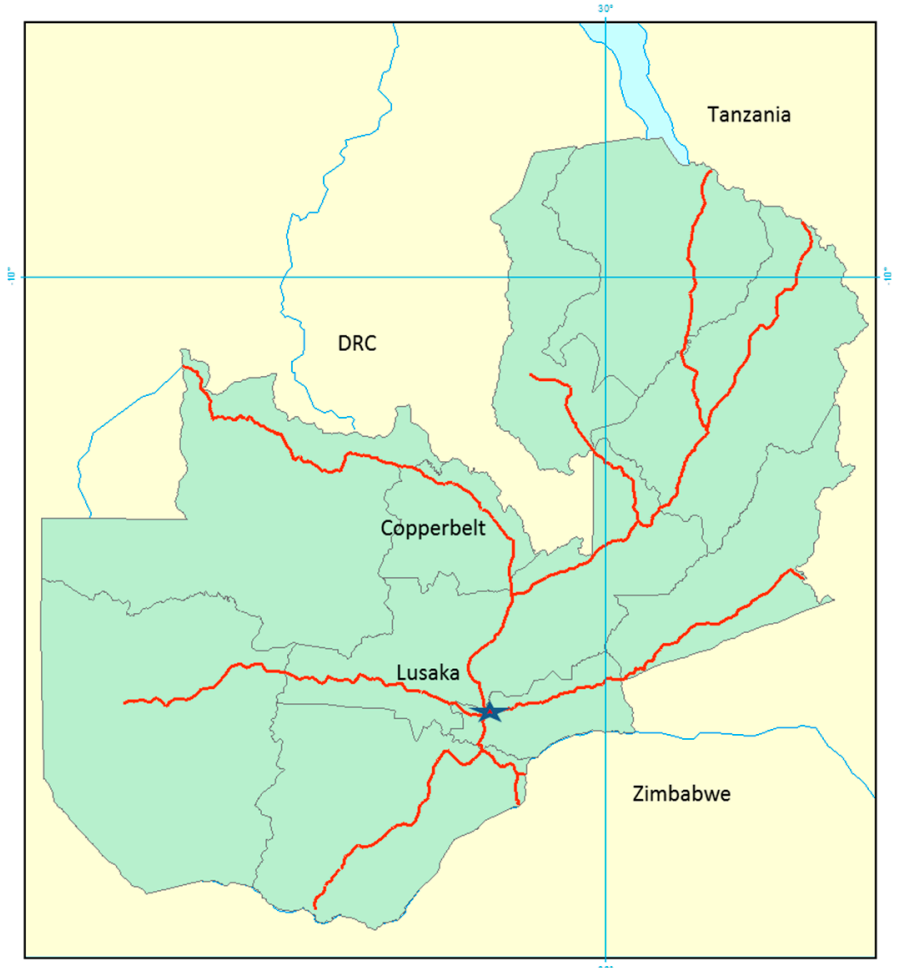

Figure 1. Zambia's "Line of Rail”.

In this section, we explore how the rapid growth in the number of medium-scale farmers in Zambia is reshaping the distribution of land and its availability to small-scale producers. Figure 2 presents a district-level map of percent changes in the share of medium-scale farmers to the total small and medium-scale farming population. It shows that the growth in the share of medium-scale farmers is geographically dispersed, but exhibits clustering around major urban centers along the line of rail. The medium-scale farm growth in the higher density, market accessible regions of the country are of particular interest for the future of small-scale agriculture. These are the regions where the majority of small-scale farmers are clustered [33] and where market access conditions are most likely to favor an agricultural-led commercialization process. As a result of superior market access conditions, these are also the areas where domestic and foreign investment interest in land is likely to be the most acute. As will be shown below, the growth of medium-scale farmers exhibits important spatial relationships with land ownership inequality, deteriorating land access conditions, and increased levels of land alienation.

The growth in medium-scale farmers has a spatial relationship with land ownership inequality. In 2009 the Gini coefficient for land in Zambia's small and medium-scale sector stood at 0.56. This represents a significantly higher level of land inequality than the 0.50 in Latin America, where land inequality was considered a major constraint to agricultural-led poverty reduction [34]. As shown in Figure 3, land inequality in Zambia has a discernible geographic pattern; land inequality is highest 
along the major road infrastructure from the capital Lusaka, northwest to the urban centers of the Copperbelt and northeast toward the Tanzanian border. These are regions with reasonably good access to domestic urban and cross border markets, as well as more stable intra and inter-seasonal rainfall patterns [35]. Land inequality is relatively low in the high density rural areas of the Southern and Eastern Provinces, where land fragmentation has likely helped to equilibrate land holding sizes overtime, and in the low density Western Province.

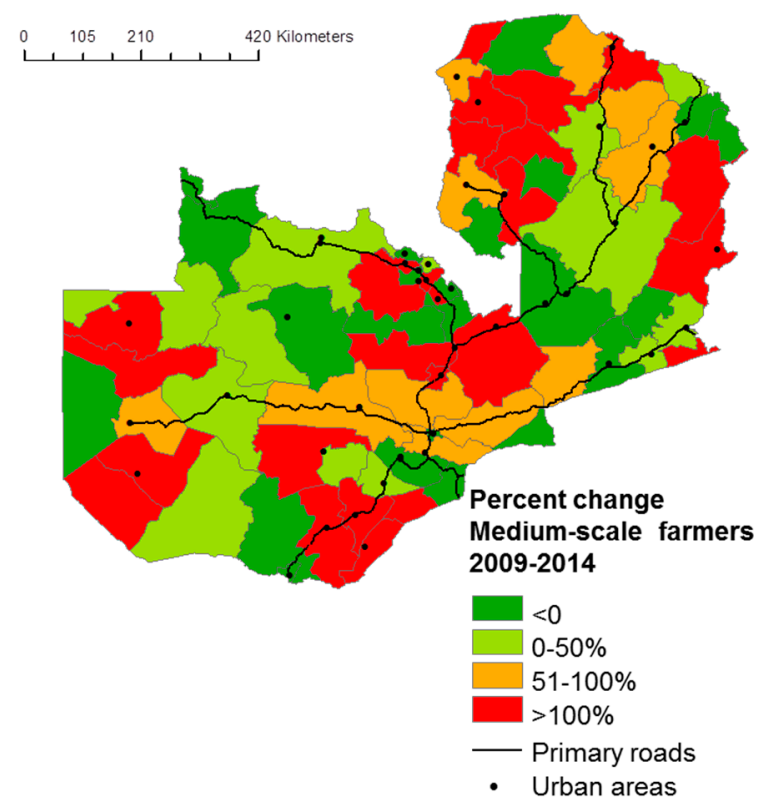

Figure 2. Percent change in number of medium-scale farms relative to the total small and medium-scale population 2009-2014. Source: computed from CFS 2009 and 2014.

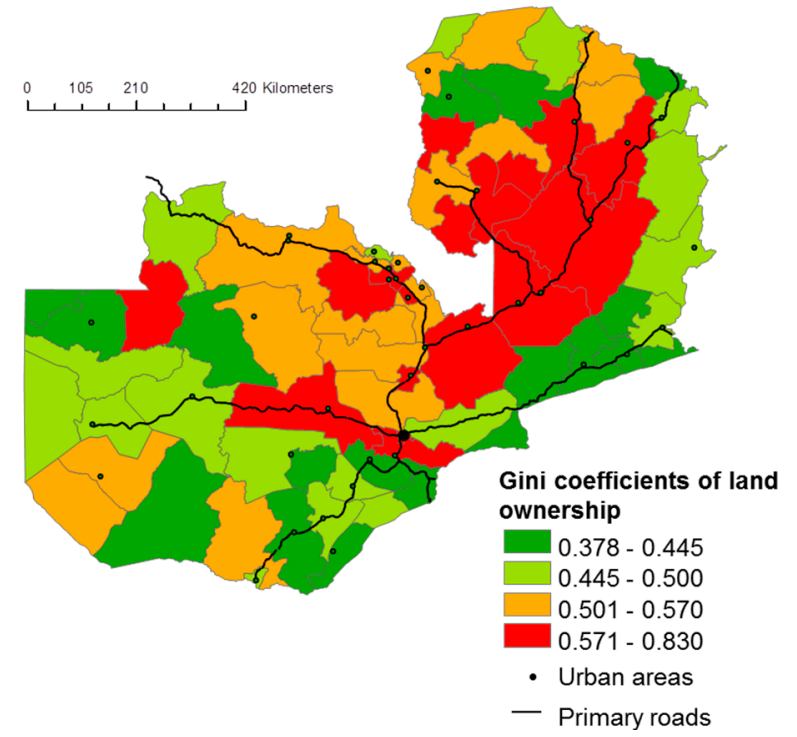

Figure 3. Gini Coefficient of small and medium-scale land holdings by district, 2009. Source: CFS 2009.

This pattern of land inequality suggests that significant numbers of larger land holdings are clustering alongside very small farms in regions with the greatest agro-climatic and market access conditions for successful agricultural commercialization under rain-fed conditions. While we cannot 
determine causal relationships between changes in medium-scale farm populations and district-level Gini coefficients, we do observe a statistically significant correlation between Gini coefficients for land at the start of our period of analysis (2009-2014) and changes in the share of medium-scale farmers to the total smallholder farming population over that period at the 0.05 level. These bivariate relationships are presented in Figure 4. In other words, at a district level, growth in medium-scale farmers is in many cases occurring in precisely the same districts where land inequality was already the highest in 2009.

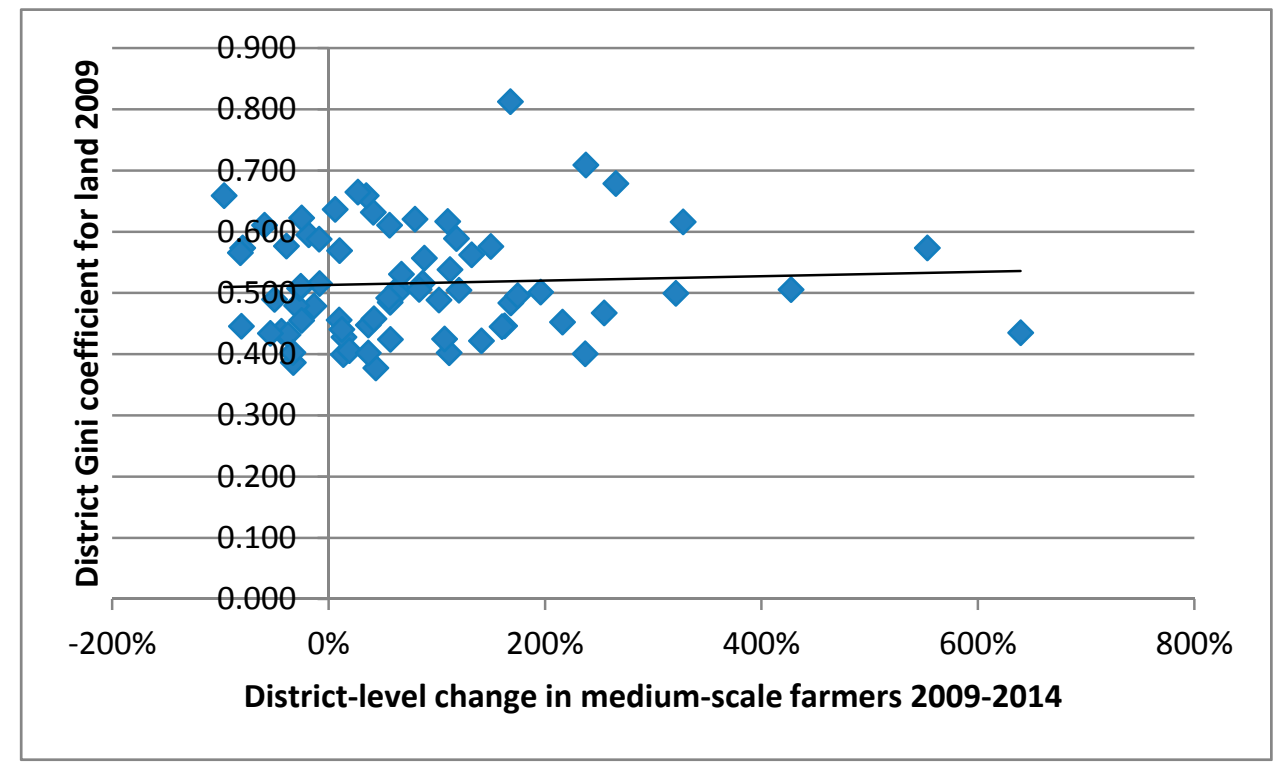

Figure 4. Scatter plot of District-level land Gini Coefficients by Changes in the Share of Medium-Scale Farms to Total Smallholder Population. Source: CFS Various Years.

In addition to fairly high levels of land inequality, a majority of Zambian farmers also report constraints to land access. At a national level 54 percent of small and medium-scale indicate that local traditional authorities do not have land to allocate to local residents. Although we do not have district-representative figures on reported land scarcities, as these questions are not asked in the CFS, Figure 5 presents indicative data from the RALS on where reported land scarcities are most acute. It shows that there is considerable overlap between districts with high levels of land inequality and the incidence of reported land scarcities. While the highest incidences of reported land scarcities occur in the high density Southern and Eastern Provinces, Figure 5 shows that in the large, and low density districts north of the capital, where Gini coefficients are particularly high, reported land scarcities exceed 50 percent of the rural population.

Enabled by the 1995 Land Act, Zambia has witnessed a significant increase in the incidence of land titling within the small and medium-scale farming sector. Based on data collected by the Ministry of Lands and presented in Sitko and Jayne (2014) [15], a total of 5098 land conversions have been recorded between 1995 and 2012, amounting to approximately 280,000 ha of customary land that is now administered through leasehold title by individuals for agricultural purposes. This represents a 3 -fold increase over the previous decade. As of 2012, 10 percent of all small and medium-scale land was titled [22]. The geographic dimensions of land alienation are important. Figure 6 presents illustrative, though not representative data, on the rates of change in land titling between 2001 and 2012. District representative 
data on land titling are not available. That being said, Figure 6 indicates that the rates of change in land titling are high for most districts along the main infrastructure corridors, and are particularly high in the areas surrounding the major urban centers of Lusaka and the Copperbelt. This indicative pattern of land alienation closely coincides with incidences of land inequality. At a district-level, we find that changes in the percent of farms with land titles are correlated (0.405) with Gini coefficients of land ownership in 2009 at a 0.001 level of significance. These relationships are presented graphically in Figure 7 . Though the data available are limited, this pattern suggests that land alienation is occurring at the highest rate in the same places where land inequality is the most pronounced.

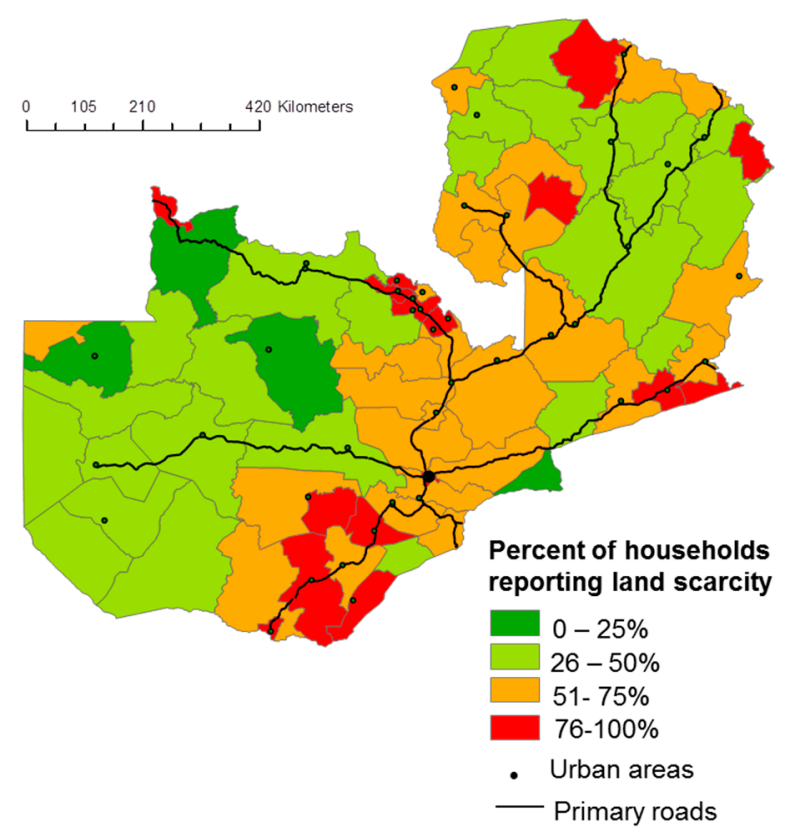

Figure 5. Percent of small and medium-scale farmers reporting that land local traditional authorities no longer have land to allocate to resident. Source: RALS 2012.

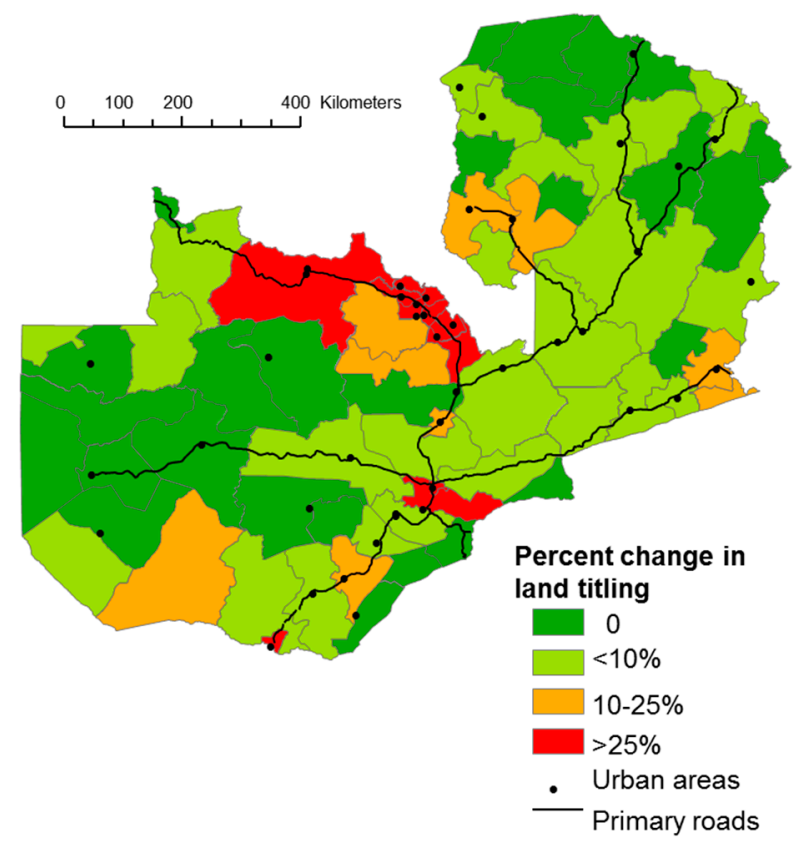

Figure 6. Change in Percent of Farms with Land Title 2001-2012. Source: RALS 2102 and SS 2001. 
Given the opaque ways in which land is alienated in Zambia's customary areas, the increased prevalence of land titling in areas where land inequality is most pronounced is worrying. Land alienation processes in Zambia have been shown to exclude the existing small-scale farm population in favor of outside domestic investors [22]. Given that land inequality is highest in regions with the highest agricultural commercialization potential, land alienation processes in those areas will likely further marginalize small-scale farmers from agricultural growth opportunities. Moreover, because levels of inequality are endogenous to the poverty reduction potential of economic growth, the dual processes of land alienation in already unequal regions will undermine the future capacity for agricultural growth to put a dent in rural poverty.

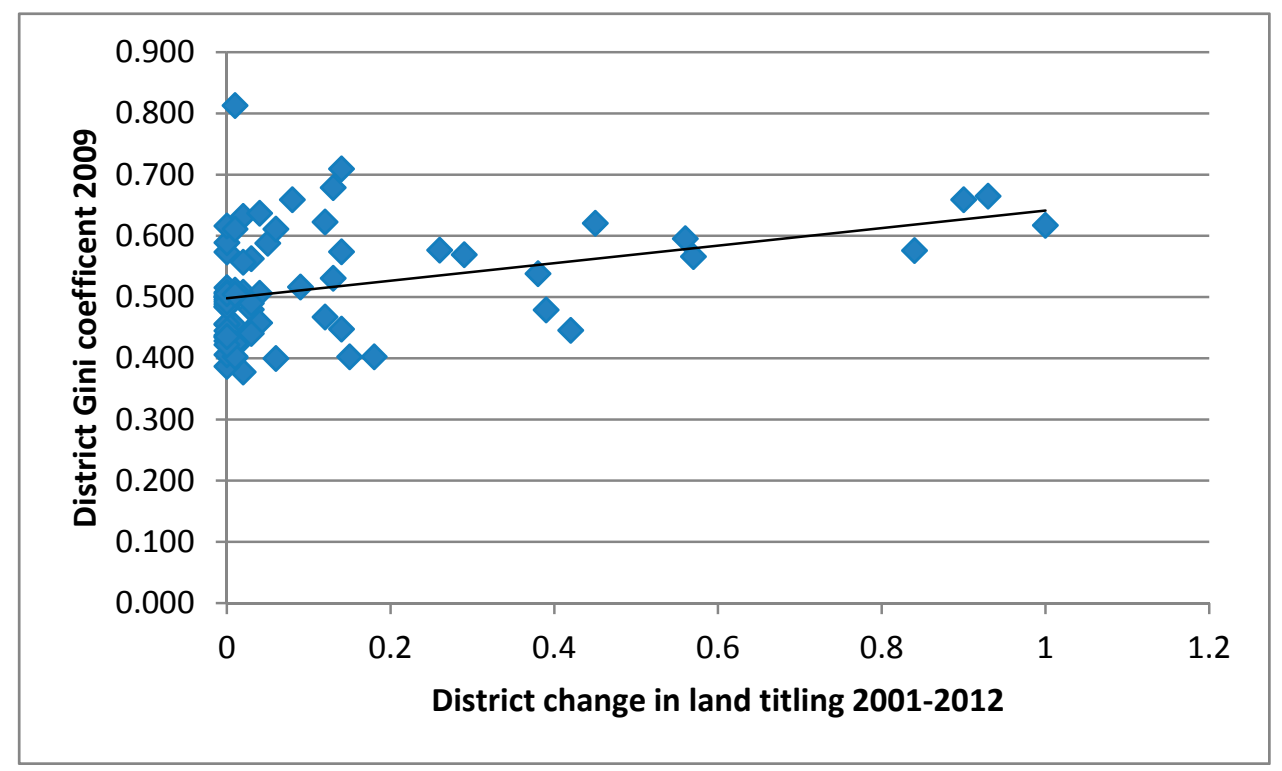

Figure 7. Scatter plot of District-level changes in Gini Coefficients, 2009, and Changes in Land Titling 2001-2012. Sources: CFS 2009, Supplemental Survey 2001 and RALS 2012.

Taken together, the geographic dimensions of the on-going land rush in Zambia suggest that in the areas where the components for a smallholder commercialization process are most likely to be successful - regions in close proximity to input and output market — are precisely the places where we see land access constraints becoming pronounced, land inequality rising, and land alienation proceeding rapidly. It is clear that as these transformations deepen, the capacity for a broad-based agricultural growth process to take hold in these viable agricultural areas will become increasingly constrained. What is less clear, however, is whether or not these transformations can help to reshape Zambia's food system in beneficial ways.

\section{Characteristics of Medium-Scale Farmers}

To understand the implications of the growth of the medium-scale land owners on Zambia's agricultural growth potential, we need to examine their socio-economic and land use characteristics relative to the average smallholder. Table 3 compares data on medium-scale land owners collected by Sitko and Jayne, with RALS household survey data on small-scale farmer. Several important points emerge from this comparison. First, medium-scale land owners in the Sitko and Jayne survey are better 
educated and more likely to be employed in the public sector than the average small-scale in Zambia, in jobs ranging from teachers, health workers, and agricultural extension workers on the one hand, to higher-level positions in government ministries, on the other. Second, a considerably larger share has alienated their land relative to small-scale farmers. Finally, though comparative data are not available from RALS, Sitko and Jayne (2014) [15]find that the majority of medium-scale farmers in their survey used non-farm wage income to acquire their land, rather than farm income, and most of these land acquisitions have been recent. Taken together, this comparison suggests that wage income growth, particularly from public sector employment, is driving a significant share of the expansion of medium-scale land ownership in Zambia. Moreover, these wage earners appear to be utilizing their knowledge of bureaucratic systems, derived from public sector employment, to navigate opaque systems for acquiring land titles, a point supported by a recent analysis of the determinants of title acquisitions in Zambia [22].

Table 3. Socio-economic comparisons of medium-scale and small-scale land owners. Source: medium-scale farmer data comes from Sitko and Jayne 2014 (N=183), small-scale data comes from RALS 2012.

\begin{tabular}{ccc}
\hline & Medium-Scale & Small-Scale \\
\hline Percent that used primarily off-farm income to acquire land & $57 \%$ & $\mathrm{n} / \mathrm{a}$ \\
Percent with title to their land & $22 \%$ & $8.4 \%$ \\
Average year of first land acquisition & 2005 & $\mathrm{n} / \mathrm{a}$ \\
Percent employed in public sector & $37 \%$ & $4.7 \%$ \\
Average duration of employment & 8.5 years & $\mathrm{n} / \mathrm{a}$ \\
Average year of education HH & 10.2 & 5.8 \\
\hline
\end{tabular}

The relationship between off-farm wage income and the land acquisitions among medium-scale land owners shown in Table 3 helps to explain the changes in household income and income inequality within the smallholder sector. Table 4 shows the percent change in real household income for mediumscale and small-scale land owners between 2001 and 2012. Several points are worth noting in this table. First, while both have seen an increase in real gross incomes, the pace of change for mediumscale land owners is considerably faster. Between 2001 and 2012, medium-scale farmers saw their real gross income expanded by $150 \%$ compared to $95 \%$ for small-scale land owners. This widening inequality is driven by more rapid increases in both agricultural and non-farm income. Of particular interest is the considerably faster pace of growth in wage incomes among medium-scale land owners. Over the period 2001 to 2012, they have seen average real wage income increase at a rate that is 90 percent faster than in the small-scale sector. This is indicative of an influx of wage earning capital into the medium-scale sector.

As shown by the rapid pace of growth in real agricultural incomes among medium-scale farmers, they appear to be having a beneficial effect on aggregate agricultural production and agricultural GDP growth in Zambia. Yet much of this related to favorable agricultural spending on medium-scale farmers. As shown by Mason et al. (2012) [36] medium-scale farmers have considerably higher supply elasticity to maize prices than small-scale farmers. As the government's spending on output price subsides for maize have increased, medium-scale farmers have responded. Mason et al. (2012) [36] estimate that every 100 
kwacha increase in government subsidy prices for maize trigger a $41.24 \mathrm{~kg}$ of maize response from medium-scale farmers, compared to a $4.29-8.47 \mathrm{~kg}$ response from small-scale farmers.

Table 4. Percent change in average real income for small-scale and medium-scale farmers by source 2001-2012. Source: authors calculations from SS 2001 and RALS 2012. CPI comes from Zambian Central Statistical Office.

\begin{tabular}{ccccc}
\hline & $\begin{array}{c}\text { Gross Household } \\
\text { Income }\end{array}$ & $\begin{array}{c}\text { Gross Household } \\
\text { Agricultural Income }\end{array}$ & $\begin{array}{c}\text { Gross Off-Farm } \\
\text { Household Income }\end{array}$ & $\begin{array}{c}\text { Household } \\
\text { Wage Income }\end{array}$ \\
\hline Small-scale & $94.7 \%$ & $129.6 \%$ & $70.9 \%$ & $55.7 \%$ \\
Medium-scale & $152.1 \%$ & $212.6 \%$ & $85.7 \%$ & $145.8 \%$ \\
Diff & $57.4 \% * *$ & $83.0 \% * *$ & $14.8 \% *$ & $90.0 \% * * *$ \\
\hline
\end{tabular}

Note: *Sig. $0.10 ; * * 0.05 ; * * * 0.0001$.

With significant subsidy support and access to wage income, medium-scale farmers are in a better position than most small-scale farmers to intensify production of low cost cereals through the acquisition of capital intensive inputs and the achievement of greater economies of scale in production and marketing. However, when land use patterns among medium-scale land owners are examined more closely a worrying trend emerges. As shown in Table 5, as the area land ownership increases the share of land that it utilized for crop production declines substantially. Even when assuming a high fallow rate, the share of land that is controlled by the medium-scale farm sector that is sitting idle is astounding. As a result, the total value of agricultural production, including the value of livestock owned by the household, per hectare is a quarter of that achieved by small-scale farmers (Table 6). Moreover, as shown in Table 6, when we calculate the value of production per hectare cultivated for small and medium-scale farmers we find that small-scale farmers tend to achieve greater returns per hectare cultivated. This finding is consistent with much of the inverse productivity literature, which shows that small-scale producers achieve greater returns per hectare than larger scale producers [37]. This difference likely reflects some combination of the production of higher value crops by land poor farmers, and greater management intensity.

This pattern of land use suggests that medium-scale farmers lack the capacity, the incentives, the inclination, or some combination of the three to bring more of their land into use. The specific reason for the under-utilization of land by medium-scale farmers likely varies spatially. In regions with good access to markets and infrastructure, where agricultural returns are likely the highest, a lack of incentives to invest in agriculture is an unlikely candidate. Instead, under-utilization of land in these high potential regions more likely represents the high opportunity costs of dedicating time and energy to managing a farm relative to time dedicated to wage income opportunities. Indeed, that many of these individuals acquired land using off-farm sources, alienated it, and are now letting much of it sit idle, suggests that a large share of these acquisitions are likely for either speculative purposes or for use after retirement. This is worrying, not only because of the high level of land inequality and land access constraints in these regions, but also because it is unclear if this land is being held for future agricultural purposes. 
Table 5. Share of land cultivated by landholding size. Source: CFS 2014.

\begin{tabular}{cc}
\hline Landholding Size Category & Share of Landholding Cultivated (2014) \\
\hline $0-2$ ha & $85 \%$ \\
$2-5$ ha & $66 \%$ \\
$5-10$ ha & $48 \%$ \\
$10-20$ ha & $35 \%$ \\
$20-100$ ha & $12 \%$ \\
\hline
\end{tabular}

Table 6. Average gross value of agricultural production (Crop+Livestock, Crop, and Livestock) per hectare owned and hectares cultivated (2012 ZWK). Source: RALS 2012.

\begin{tabular}{ccccc}
\hline & \multicolumn{3}{c}{ Per Hectare Owned } & Per Hectare Cultivated \\
\cline { 2 - 5 } & Crop and Livestock & Crop Value & Livestock Value & Crop and Livestock \\
\hline Small-Scale & $8,036,705.67$ & $7,093,641.96$ & $943,063.71$ & $8,284,821.38$ \\
Medium-Scale & $2,250,099.34$ & $2,048,161.97$ & $201,937.37$ & $4,438,178.97$ \\
\hline
\end{tabular}

\section{Conclusions}

Strategies to increase agricultural productivity on African land are thought to occur through one of two primary pathways; by attracting investment in large-scale commercial production or through intensification on existing smallholder plots. While considerable sums have been spent to further each of these strategies, and considerable ink spilled in defending or opposing them, an under-recognized transformation is taking place that will have important implications on both. The rapid expansion of medium-scale landholders in Zambia, and indeed in other countries in the region [13], is altering the agricultural landscape in ways that may place boundaries on the feasibility of a smallholder-led agricultural growth strategy and will exacerbate the land availability implications of large-scale land acquisitions. Recognizing the causes and consequences of this middle-tier landholding transformation is critical if African agriculture growth is to achieve outcomes that are consistent with the stated poverty reduction, food security, and economic growth objectives of policy-makers.

This article has shown that the expansion of medium-scale farmers in Zambia is, in part, driven by an on-going domestic land rush. This rush is characterized by a growing segment of wage earners utilizing permissive and opaque land policies to acquire, and in many cases alienate, sizeable tracts of land. Growth in the share of medium-scale land owners and processes of land alienation are occurring in places where land inequality is particularly pronounced. These are the same places that, due to favorable market access and rainfall conditions, also hold the highest potential for agricultural commercialization. Moreover, in some areas of the country, these landscape transformations are occurring in tandem with foreign-owned land acquisitions, thus further exacerbating land access and inequality challenges.

Agricultural spending by the government of Zambia is also an important driving force in this transformation. A significant escalation of spending of maize subsidies has been captured predominantly by the medium-scale farm sector. These subsidies are likely enabling some consolidation in the smallholder sector and act as incentives for wage earner investment in agriculture. Interestingly, while 
these subsidies have coincided with a large increase in aggregate maize production, there has not been a significant decline in maize meal prices [26].

This process of medium-scale farm growth is leading to an under-utilization of agricultural land and is stifling agricultural output per hectare, as many medium-scale land owners are utilizing a small portion of their available land for food production purposes, and achieving agricultural returns per hectares of land owned and cultivated that is a fraction of those attained by small-scale farmers. This raises additional concerns about the near-term implications of this land rush on aggregate food production and food prices.

Yet, the medium to long-term consequences of this land rush are more worrying still. Given the limited pace of wage labor market expansion, ensuring viable opportunities for small-scale farmers in the medium-term is essential if Zambia, and other African nations, are to cope with the large and growing number of young people entering the labor force each year [38]. Through the alienation of land in high potential areas and the exacerbation of land inequality conditions, this domestic land rush is foreclosing the potential for future generations of small-scale farmer to acquire viable parcels of land, to link to a virtuous cycle of input intensification and output market engagement, and ultimately, to contribute to a smallholder-led economic transformation.

The ways in which medium-scale land owners are reshaping the agricultural landscape suggest that even in low density countries such as Zambia the capacity to utilize the agricultural sector and agricultural spending to achieve broad-based growth and poverty reduction objectives are fundamentally tied up with land policy. As African food production comes to play an increasingly important role in the future of the global food system, it is critical that domestic policy-makers and international donors recognize the important intersections between land policy, land distribution, and agricultural development outcomes. In order to meaningfully affect the enduring problems of rural poverty and hunger requires a more explicit recognition of how land policies are shaping the current and future prospects of Africa's rural poor.

What can be done from a policy perspective to retain viable land access opportunities for existing small-scale farmers without stifling potentially valuable domestic investment in agriculture? An important place to begin is to provide a clear framework for protecting the land rights of current smallscale farmers, particularly in regions witnessing significant domestic investor interest in land. This may entail land mapping exercises with traditional authorities, which can demarcate small-scale farming areas and areas where external investments can occur. This must be coupled with a change in land taxation systems for titled land. Land taxes in Zambia are currently negligible for land title holders. This allows individuals with no immediate interest in utilizing land to acquire it and sit on it for years. Increasing land taxes will increase incentives to invest in land and will limit speculative acquisitions. More fundamentally, Zambia needs to implement an overarching land policy that seeks to balance the social and economic objectives of the country. Until a land policy is in place, pressure from domestic investors to acquire valuable farm land will continue unabated, to the detriment of future generations of small-scale farmers. 


\section{Acknowledgments}

The authors would like to acknowledge the generous funding provided for this research by the United States Agency for International Development through its support for the Food Security Research Project (FSRP).

\section{Author Contributions}

Nicholas Sitko led the writing and analysis, with support from Jordan Chamberlin.

\section{Conflicts of Interest}

The authors declare no conflict of interest.

\section{References}

1. McMichael, P. A food regime genealogy. J. Peasant Stud. 2009, 36, 139-169.

2. Cotula, L. The Great African Land Grab? Agricultural Investments and the Global Food System; Zed Books: London, UK, 2013.

3. Thurow, R. The fertile continent: Africa, agriculture's final frontier. Foreign Aff. 2010, 102-110

4. Deininger, K.W.; Byerlee, D. Rising Global Interest in Farmland: Can it Yield Sustainable and Equitable Benefits? World Bank Publications: World Bank, Washington, DC, USA, 2011.

5. Schoneveld, G.C. The geographic and sectoral patterns of large-scale farmland investments in Sub-Saharan Africa. Food Policy 2014, 48, 34-50

6. Woodhouse, P. New investment, old challenges. Land deals and the water constraint in African agriculture. J. Peasant Stud. 2012, 39, 777-794.

7. Mowlds, S.W.; Nicol, E.; Cleirigh, O. Aid for Food and Nutrition Security; OECD Report; 2012. Available online: http://www.oecd.org/dac/povertyreduction/ Brochure\%20on\%20Food\%20Security\%20FINAL\%2013\%20July\%202012.pdf (accessed on 4 January 2015).

8. Benin, S.; Yu, B. Complying with the Maputo Declaration Target: Trends in Public Agricultural Expenditures and Implications for Pursuit of Optimal Allocation of Public Agricultural Spending; ReSAKSS Annual Trends and Outlook Report; International Food Policy Research Institute: Washington, DC, USA, 2012.

9. Diao, X.; Headey, D.; Johnson, M. Toward a green revolution in Africa: what would it achieve, and what would it require? Agric. Econ. 2008, 39(Suppl. 1), 539-550.

10. Djurfeldt, G.; Holmen, H.; Jirstrom, M.; Larsson, R. The African Food Crisis: Lessons from the Asian Green Revolution; Cabi Publishing: Wallington, UK, 2005.

11. Collier, P.; Dercon, S. African agriculture in 50 years: Smallholders in a rapidly changing world? World Dev. 2014, 63, 92-101.

12. Hazell, P.; Poulton, C.; Wiggins, S.; Dorward, A. The future of small farms: Trajectories and policy priorities. World Dev. 2010, 38, 1349-1361.

13. Jayne, T.S.; Chapoto, A.; Sitko, N.; Nkonde, C.; Muyanga, M.; Chamberlin, J. Is the scramble for land in Africa foreclosing a smallholder agricultural expansion strategy? J. Int. Aff. 2014, 67, 35. 
14. Pingali, P.L. From subsistence to commercial production systems: The transformation of Asian agriculture. Am. J. Agric. Econ. 1997, 628-634.

15. Sitko, N.J.; Jayne, T.S. Structural transformation or elite land capture? The growth of "emergent" farmers in Zambia. Food Policy 2014, 48, 194-202.

16. Muyanga, M.; Jayne, T.S. Effects of rising rural population density on smallholder agriculture in Kenya. Food Policy 2014, 48, 98-113.

17. Moyo, J. Land Seizures Speeding Up, Leaving Africans Homeless and Landless; International Press Service: Harare, Zimbabwe, 2015. Available online at: http://www.ipsnews.net/2015/04/ land-seizures-speeding-up-leaving-africans-homeless-and-landless/ (accessed on 04 March 2015).

18. Berry, S.; Downs, R.E.; Reyna, S.P. Concentration without privatization? Some consequences of changing patterns of rural land control in Africa. In Land and Society in Contemporary Africa; University Press of New England: Lebanon, NH, USA, 1988; pp. 53-75.

19. Bruce, J.W. A perspective on indigenous land tenure systems and land concentration. In Land and Society in Contemporary Africa; University Press of New England: Lebanon, NH, USA, 1988; pp. 23-52.

20. German, L.; Schoneveld, G.; Mwangi, E. Contemporary processes of large-scale land acquisition in Sub-Saharan Africa: Legal deficiency or elite capture of the rule of law? World Dev. 2013, 48, $1-18$.

21. Mamdani, M. Citizen and Subject: Contemporary Africa and the Legacy of Late Colonialism; Princeton University Press: Princeton, NJ, USA, 1996.

22. Sitko, N.J.; Chamberlin, J.; Hichaambwa, M. Does smallholder land titling facilitate agricultural growth?: An analysis of the determinants and effects of smallholder land titling in Zambia. World Dev. 2014, 64, 791-802.

23. Brown, T. Contestation, confusion and corruption: Market-based land reform in Zambia. In Competing Jurisdictions: Settling Land Claims in Africa; Brill Publishing: Leiden, The Netherlands, 2005; pp. 79-102.

24. Nolte, K. Large-scale agricultural investments under poor land governance in Zambia. Land Use Policy 2014, 38, 698-706.

25. Tschirley, D.; Reardon, T.; Dolislager, M.; Snyder, J. The rise of a middle class in East and Southern Africa: Implications for food system transformation. J. Int. Dev. 2015, 27, 628-646.

26. Sitko, N.J.; Kuteya, A. The Maize Price Spike of 2012/13: Understanding the Paradox of High Prices despite Abundant Supplies; IAPRI Working Paper 81; 2013. Available online: http://fsg.afre.msu.edu/zambia/wp81.pdf (accessed on 05 January 2015).

27. Mason, N.M.; Jayne, T.S.; Mofya-Mukuka, R. Zambia's input subsidy programs. Agric. Econ. 2013, 44, 613-628.

28. Sitko, N.J. 'My hunger has brought business': 'Efficiency' and the de-moralizing logic of maize distribution in an era of market liberalization. J. Peasant Stud. 2013, 40, 379-396.

29. Jayne, T.S.; Mason, N.; Burke, W.; Shipekesa, A.; Chapoto, A.; Kabaghe C. Mountains of Maize, Persistent Poverty; Policy Synthesis No. 48; 2011. Available online: http://fsg.afre.msu.edu/ zambia/ps_48.pdf (accessed on 03 January 2015).

30. Johnston, B.F.; Mellor, J.W. The role of agriculture in economic development. Am. Econ. Rev. 1961, 51, 566-593. 
31. Mellor, J.W. New Economics of Growth; Cornell University Press: Ithaca, NY. USA, 1976.

32. Johnston, B.F.; Kilby, P. Agriculture and Structural Transformation; Economic Strategies in Late-Developing Countries; Oxford University Press: Oxford, UK, 1975.

33. Jayne, T.S.; Chamberlin, J.; Headey, D.D. Land pressures, the evolution of farming systems, and development strategies in Africa: A synthesis. Food Policy 2014, 48, 1-17.

34. Deininger, K.; Squire, L. New ways of looking at old issues: inequality and growth. J. Dev. Econ. 1998, 57, 259-287.

35. Jones, P.G.; Thornton, P.K. The potential impacts of climate change on maize production in Africa and Latin America in 2055. Glob. Environ. Change 2003, 13, 51-59.

36. Mason, N.; Jayne, T.S.; Myers, R.J. Zambian Smallholder Behavioral Responses To Food Reserve Agency Activities (Revised Version); IAPRI Policy Synthesis No. 57; Indaba Agricultural Policy Research Institute: Lusaka, Zambia, 2011. Available online: http://fsg.afre.msu.edu/ zambia/ps_57.pdf(accessed on 03 January 2015).

37. Larson, D.F.; Otsuka, K.; Matsumoto, T.; Kilic, T. Should African rural development strategies depend on smallholder farms? An exploration of the inverse-productivity hypothesis. Agric. Econ. 2014, 45, 355-367.

38. Losch, B. Migrations and the challenge of demographic and economic transitions in the new globalization era. In Proceedings of the SSRC Migration \& Development Conference on Future Directions for Research and Policy Panel \#4, New York, NY, USA, 28 February-1 March 2008; pp. 2-14.

(C) 2015 by the authors; licensee MDPI, Basel, Switzerland. This article is an open access article distributed under the terms and conditions of the Creative Commons Attribution license (http://creativecommons.org/licenses/by/4.0/). 